\title{
Shep Parson on Material Culture and Protestant Ministry
}

\section{Interviewed by Ashley Makar}

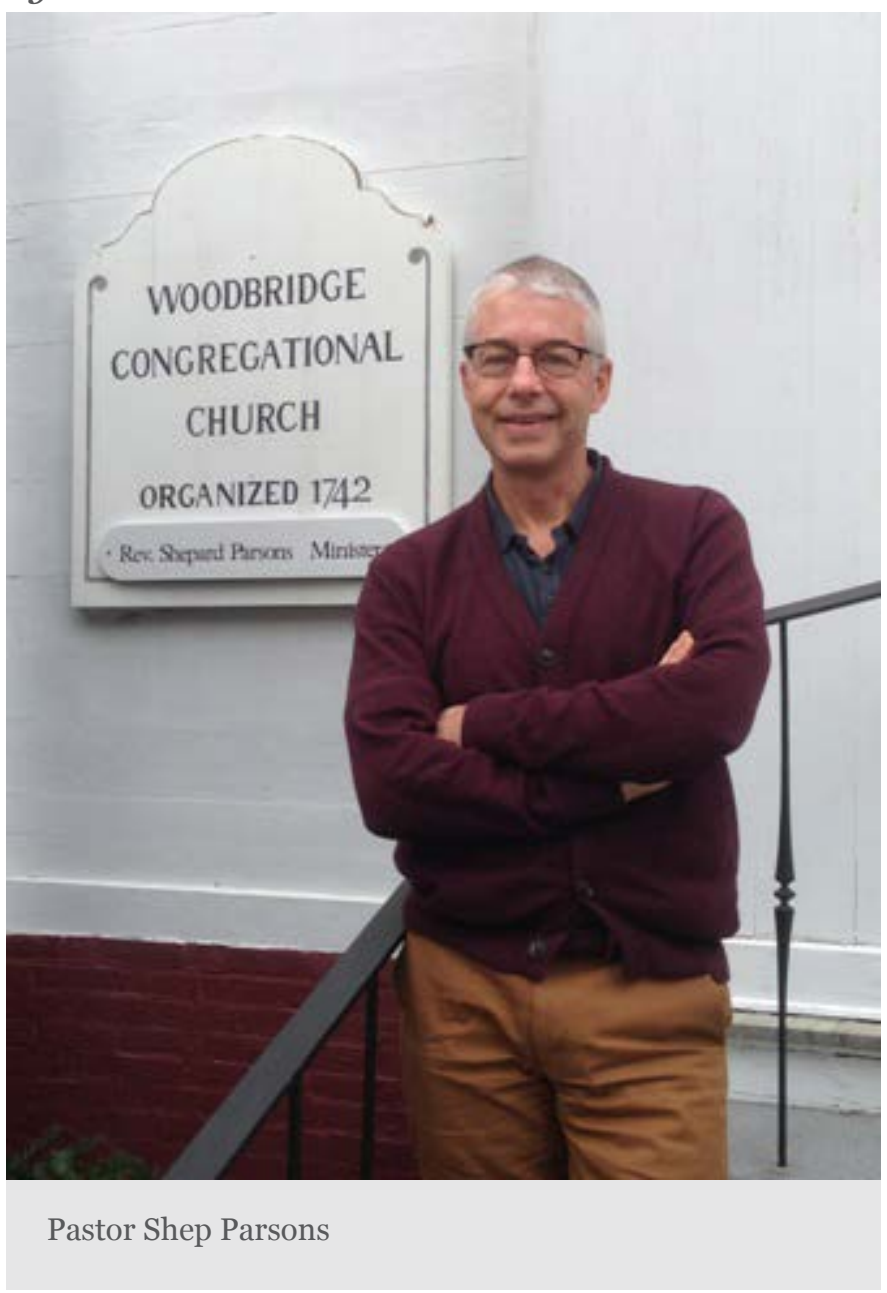

Ashley Makar interviewed Shephard (Shep) Parsons in 2011 when Parsons was minister at Shelton Congregational Church in Shelton, Connecticut. He is currently Senior Pastor at First Church of Christ, Woodbridge, Connecticut.

Ashley Makar: What sorts of arts education have you had?

Shep Parsons: Well, in college I had an interdisciplinary course in the arts of writing, literature, music, and visual arts.

Ashley Makar: Where did you go to school?

Shep Parsons: Furman in Greenville [South Carolina]. I took a creative arts workshop. I took an eight-week course but only could do three weeks. It was during the week and I just couldn't make it. But in 1992, my wife at the time Serena and I went out to Ghost Ranch for a vacation for a month and a friend of ours who is a trained artist came out for a week and we would hike and sit and draw and paint. I was smitten by that. So actually, any kind of art education that I've had was from Katie Kindelan who was the art teacher 
at Edgewood School. And so I guess with her help I'm a painter as well.

Ashley Makar: You are? And do you feel that you are producing religious art?

Shep Parsons: Well, I don't think it could be otherwise for me because I'm a person of faith. So that work which I produce has my faith and perspective in it. Not that I'm drawing crosses or anything but I just kind of tell the mystery and brilliance. I like colors a lot. But because of that, I really look at the world differently, I think.

Ashley Makar: Because of your painting practice?

Shep Parsons: Yes. It began actually back when I was in college. I studied the Impressionists while I was in Europe and through their perspective began to look at things differently. I looked closely; it's a visually different way of walking through the world.

Ashley Makar: And has that influenced your ministry?

Shep Parsons: Well, in preaching I use a lot of imagery and narrative which are kind of a verbal mode of truth. I've played with color and objects and images in the course of worship. I've come to really appreciate congregations' love of and determination to keep the images that they have. People have a really spiritual attachment to these fixtures and things like that.

Ashley Makar: What kind of images for example?

Shep Parsons: Well, it's very interesting. Back in the 70s, Edgewood Congregational Church was one of the churches that had grown out of Center Church and it merged back with Center Church. And the folks at Center Church were really into their iconoclasm. You know, no images except for the image of John Davenport. ${ }^{1}$ [laughter] But Edgewood wanted to bring, as part of their bringing part of themselves back in this congregation, one of their crosses, their little bronze cross to sit on the table. And it almost sunk the merger.

Ashley Makar: Really?

Shep Parsons: Yes. So I had to really work through that.

Ashley Makar: How so?

Shep Parsons: How important the cross was, that image was for them. Both, I think, as a symbol of the church from which they were coming as well as a way to kind of focus their own faith. And for Center Church, again, it's so ironic that they wouldn't have any symbols except for John Davenport, the Tiffany of John Davenport looming above all.

Ashley Makar: So they decided to allow the cross? 
Shep Parsons: And so the cross sits on the table, on the community table.

Ashley Makar: And what was the aftermath?

Shep Parsons: I don't remember. I mean that was in the 70s. I didn't show up until '91. But it was still being talked about. [laughter]

Ashley Makar: Really? Wow.

Shep Parsons: Oh yes. It was still kind of like, we were the folks from Edgewood; we were the folks that weren't from Edgewood. I served a church in Waterbury, South Congregational Church, and it was originally the merger of a Methodist and Baptist congregation. And they were really Baptist and Methodist congregations until the church burned down and they decided to rebuild on the site. Out of those flames, they became South Congregational Church. They were no longer identifying themselves as

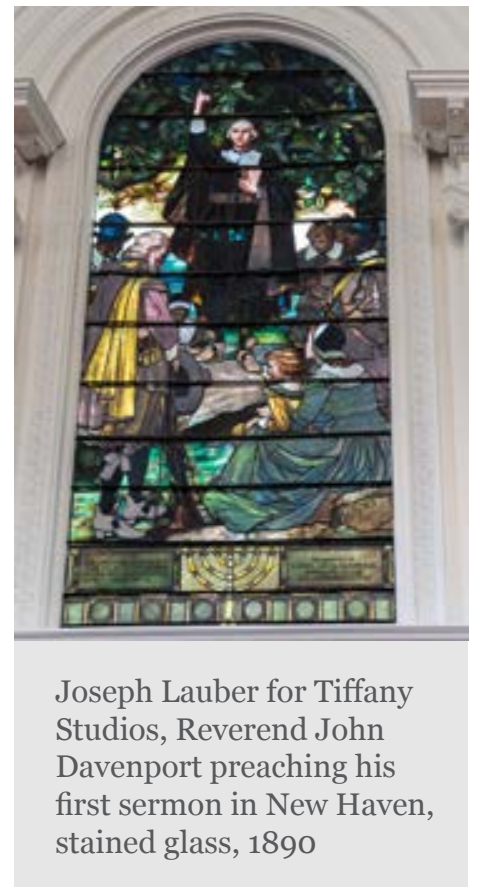

formerly Baptist or Methodist but they were part of the United Church of Christ.

Ashley Makar: And have images and objects played any role in your professional or theological training?

Shep Parsons: Well, I took a great course with John Cook and Peter Hawkins back when [at Yale Divinity School where Parsons did his Masters of Divinity]. Religion and the Arts. We read Murdock [probably a reference to Dorothy Murdock, a writer and proponent of the idea that there was no historical Jesus], Flannery O'Connor.

Ashley Makar: Walker Percy, maybe? 
Shep Parsons: Walker Percy. Yes. And we looked at paintings. It was kind of the training of the eye and the mind's eye to look at the world and faith and texts.

Ashley Makar: And you mentioned that you use images a lot in preaching. Do you mean more like a piece of art or you mean sort of an image from life?

Shep Parsons: Image from life. But, I mean, art does have an influence, I think.

Ashley Makar: Right, right. But you wouldn’t preach on a painting per se?

Shep Parsons: No, but I have-there's one great painting. I forget. I want to say Cranach was the painter but I don't really remember [Parsons is referring to the Matthias Grünewald's Isenheim altarpiece]. It's of Jesus, it's awful, awful, one of the early depictions of Jesus suffering with sores and bugs crawling all over him and John the Baptist is pointing to him and says, "I must decrease so He must increase." He's got this swollen finger pointing to Jesus. And it's interesting because Tillich loved the painting because you can't worship this guy on the cross. It's so awful and broken and you just can't put your ultimate concern in this figure.

And Barth likes it because it's Christocentric and John is saying, “That's the one. That's the one." I have these two really different theologians who could appreciate and find in the same painting a kind of a visual image of their theology. I've talked about that in Bible study.

Ashley Makar: Do you consider what you wear when you're leading services?

Shep Parsons: Of course. Of course, I do. And I quit wearing a robe a long time ago. Actually, I used to wear robes and in the summer people would say, "Don't wear your robe. It's so hot.” And so I started doing that. And I think, after I left Center Church, I really just pretty much quit wearing a robe except on special occasions. I wear a suit. I love the color of ties. I pay attention to my ties because it's the only real color men are allowed to wear, so I push it. But that's mainly it. For weddings, for funerals, then I'll put on a robe. But I really-I want to be dressed like everyone.

Ashley Makar: Did you feel like you needed to wear robe at Center Church?

Shep Parsons: There was just a greater expectation. I know that there are some folks at Shelton [Congregational Church] that would like to see the robe. But I feel freer to be fully engaged in the world of worship if I'm not wearing a robe.

Ashley Makar: And in what ways do you address spaces and movement in worship?

Shep Parsons: You know, you get into the ritual and it's all the same space, pretty much the same movement. There are different points in the morning where movement can change. Usually, when there's transitions like a children's message or the offering, the passing of the peace. There can be different kinds of movement and exchange taking 
place during those moments. But we have a very small choir. We don't process. Since I'm free to leave the pulpit if I want to I've begun singing in the choir. We moved the time of worship so I could sing, pushed it back 30 minutes so I can write my sermon and then get in an hour of rehearsal with the choir. We tried to figure out how to do that and not be too distracting, moving from prayer to choir.

Sometimes, for the purpose of what's being done that morning, I'll tweak things just a little bit, move things. Once at Center Church I was preaching on the unsettling nature of God's grace, and how it really pushes off center. And so before the morning worship, some of the deacons and I went in and we moved the table. Everything's lined up in a grid and we moved the table a little bit and turned the cross, made the parapets unequal.

The chairs are usually in order so we moved them around. It wasn't much. But people came in and were really anxious or disturbed by this little movement of some of the things in their space. And then at the end of the service, during the last hymn, we went and we put everything back in order, the resolution to it. Well some people were like, "Wow, that was just incredible." Others were so pissed, "How dare you mess with our worship space!"

Ashley Makar: And did you address that explicitly in the sermon? About the space being set up differently without people expecting that?

Shep Parsons: Absolutely. Yes, yes. That was part of a touchstone in the preaching.

Ashley Makar: And was it afterwards that they were expressing their disappointment?

Shep Parsons: Yes, at the coffee hour. There were folks that stormed over and there were other folks that were like "Wow."

Ashley Makar: And what about the choice to resolve it in that way by putting it back?

Shep Parsons: Well, at that time I had a worship committee working with me and the group decided that it was important to give some resolution.

An interesting thing about Center Church, there was a co-pastor, Campbell Lovett, and they are about 40 people at worship and the committee said, "We want to grow." And so Campbell and I really took that to heart. So we invited friends and family and we really went and reached out. And so we had a new member service in October or something like that, and when new members stood up there was a gasp. Didn't look like us. A lesbian couple, an interracial couple, two people from the street. There's just this real mix of folks. And so off and running, there was this tension about who the members wanted to be, the original members, who they thought they wanted to be and who was actually coming to our church. And it was really hard because it was difficult to work with the hymnal and the structured worship and that kind of stuff so it's a sign that we needed to have a second service. 
And we were getting about 40 people with the second service. It was very informal. We came down at front. We sat around on the floor and chairs. There were children running around. And we were still intimidated-I think that's the word-by the space. So a friend who had become a member of the church, John Geter, he was a pastor and came back to [Yale University to] do a PhD in theology. When he left his church in Sayville in New York [Sayville Congregational United Church of Christ], they had created for him this gorgeous banner. It was ribbons, different ribbons. And everybody would either write a little note or there was a catalog. So it's about four, four and a half feet wide, it was maybe five feet long, it had little bells on it. And it's bright and moved with the wind. So we brought that in, set it in front of us and that became the focus of our worship for the second service. In this huge space and John Davenport looking down on us, but here was this moving, lively, bright tingling presence enlightening us with the spirit. And so it just opened up to us the ability to be centered to the spirit and to find comfort in the space. Such that after about a year so, folks said, "You know, we want to move back in to the big worship but we'd like to have our banner up here." So we did that. And to me, that's just a real, very concrete and very cool example of what a visual piece can do for a worshipping community.

Ashley Makar: And did that also have an effect in terms of integrating the new people with the old?

Shep Parsons: I think to some degree, it did. You know, I love serving at Center Church, it's a very, very difficult ministry. The majority of folks who were there when Campbell and I arrived were embracing and welcoming but there were those who really kind of held the power who made it very [difficult]. But I think if you were to go there now, you would find a large number of the folks there worshipping and in leadership are those folks who came in.

Ashley Makar: And what were the older people attached to?

Shep Parsons: You know, a variety of things. I don't know if I can really get inside their heads but my sense is that some were attached to the building, that it was historic. I know people that came and joined the church because of its historic nature, the church and its tradition. And it had a huge endowment. It went from like three million to over ten million while I was there. I think because of its wealth there were some people who for whatever reason didn't feel they have much power in the rest of their lives and that they could come here in this wealthy institution and manage its funds. There's some people who came here because their parents and grandparents and great great great grandparents came, then there were those newer folks who were excited about being in the middle of town, middle of the city, on the green and all the life that is there and the diversity of it, and the edginess of it.

Ashley Makar: That's an interesting location for such traditional institution. How do you understand the arts to be resources for your leadership?

Shep Parsons: Well, primarily they inspire me. I am given energy and insight to work 
with. Folks in the church-it takes place in small ways, yet-should we change the hangings? Should we get new hangings, should somebody make them, a quilt? I guess about four years or so ago we go to raise money, we made a quilt and it was made up of swatches with different symbols of quilts on the Underground Railway.

Ashley Makar: Now, this was at Shelton?

Shep Parsons: In Shelton. And so it was something that kind of organized the community because it was a big quilt. A lot of people were engaged in making it happen. On the day of the raffle, we had a woman who had never preached before but was a historian of the Underground Railroad in Connecticut and she came and preached and brought folks and it was a great day. We had a luncheon afterwards. That quilt was really visually breathtaking. They had studied about what went on, about what the symbols meant. And to have that in our place of worship for several weeks, it was really, really so [wonderful]. It took so much work, a lot of organizing.

Ashley Makar: How do images, objects and the arts, and/or sensory experience relate to your leadership?

Shep Parsons: Well, I take the incarnation of God in Jesus very seriously. I understand that to be a blessing of a material world, and that God speaks to us not just orally or in the visual world, but that's why we commune something that we see, we feel, we taste, we smell. Baptism is fluidity and the feel of the water, the sound of it. I take that seriously. And I try to do things in worship.

We had great service on Palm Sunday, Palm Passion Sunday. Being a good congregation as we are, we go to church on Palm Sunday and really don't show up again until Easter. So the service takes us through the week to laying Jesus in the tomb with seven scripture readings and symbols. And so there's sight involved. There's the sound of washing of the feet. You know, it's the water being lifted up and on into the bowl, 30 pieces of silver always comes before the offering. And the person takes the money and throws it. Even though they've seen it before, they're always startled by it. We hear the tinkling of the money kind of fade off until the last one falls, get somebody who can hit a nail on the head and as we whale away at these huge nails on the cross.

And then we do a Maundy Thursday service but not as many people come out.

Ashley Makar: And do you do foot washing in that service?

Shep Parsons: No, we haven't. I've done it before but we haven't.

Ashley Makar: Do you think that would be in some way risky?

Shep Parsons: It is. It is risky. We did it a couple of times at Center Church and it really is such an intimate [experience]. We hide our feet behind shoes and socks and to have someone hold your gnarly feet in their hands and to wash them and touch [them] is 
really a very risky thing. It's so powerful.

Ashley Makar: And how did it go over there?

Shep Parsons: Oh people were just amazed.

Ashley Makar: What's your religious background?

Shep Parsons: I tell folks, I was born a Presbyterian, raised a Methodist, educated a Baptist, became a Disciple [Parsons is referring to Christian Church (Disciples of Christ), a mainline Protestant denomination] and I served in the United Church of Christ. Went to a Methodist church with 3,000 members in Orlando growing up. Campus Crusade in high school. I had my Campus Crusade friends and then I had my friends who would go off and smoke. I tried to hold that in balance. I went to Furman. I guess I've always been baffled about my faith and interested in those kinds of questions. A chaplain suggested I go to a divinity school and even suggested that I go here. So I applied some place else, PSR [Pacific School of Religion], got in, deferred for three years. I worked in services in Greenville [South Carolina] and then came here. And I wanted to be ordained but I wanted to do urban work. I wanted to organize, community organizing but with the license of ordination.

And the Methodists at that time in Florida were really not interested in that. I looked around me, and my best friends and the leadership of the school and the student body were Disciples, so I began to ask if they would ordain me. So I became a Disciple.

Ashley Makar: And did you go on to do some organizing work?

Shep Parsons: Yes. Yes, I did. But I was going to go to law school. I wasn't ready to go on to the parish. I was accepted in law school and then again decided to defer a year. I just needed a break. And then in the meantime I get an internship, the Warburton Urban Internship in Hartford. And that was kind of community organizing and part time working in the church. And part of what I did in the church was teach the adult Bible class. And at the end of my year, they sat me down one Sunday. I came prepared with a lesson and they said, "No, we're going to teach you, you listen to us." And they said, "You need to be in the parish. You are good at this and this and this and you like to do this and this and this and that's what pastors get to do and so..."

So I went through a call to ordination. They don't do that anymore. I got a call to South Church Waterbury. I like Barth, I'm greatly influenced by womanist and liberation theology. Serena and I traveled, I finished up my last year before exams we went to Sri Lanka, Hong Kong, the Philippines and South Korea. They do a lot of organizing in Waterbury. [We formed] a coalition of unions and churches and small business associations like the Northwest Connecticut Chamber of Commerce. You start with a stop sign and the next thing you know you're building a hundred and ten square feet of affordable, self-owned and managed housing. 
Ashley Makar: That's so amazing and important to happen in Connecticut. The disparities are so bad. And Waterbury, particularly.

Shep Parsons: I think so. And I think about my own relationship experience, I have to say Serena's and my divorce was a very important moment. I struggled with the idea. You know, Paul says love lasts forever. It never ends. And I was really struggling with forgiveness. It really, I think, has opened me, my heart, and theology up to a really expressively grace-filled perspective on things.

Ashley Makar: What sorts of images and objects do you remember from your childhood or your past?

Shep Parsons: Well, I remember the old sanctuary. First Methodist [Orlando, Parson's church growing up] was kind of circular and it rose up and the pulpit and the table and were down here. I remember that kind of surrounding feeling. It was wood. It was very hot. You had fans in your hands that you would use.

The other thing is when we moved across the street; it was a more Greek-Roman kind of thing, huge columns inside, and that sense when you walk in. The Women's Society at First United Methodist made these banners that are probably 14 feet long if not longer, one for each of the disciples. They researched it and each one has a particular iconography for that disciple. They're just stunning, stunning to look at. And all are a figure, except for Judas, which is just black and a moneybag. I never will forget, it was an Easter Sunday and to worship someone had tacked a sign up on Judas's banner and it said, "You too are forgiven." Whoa.

Ashley Makar: Wow. That's really powerful.

Shep Parsons: Yes. It turns out it was my old man. I didn't know it at that time. [laughter] But yes, he had gone in and done that. It really caused a lot of conversation. They're these images that you are used to and just a little tweak really makes people think differently. Kind of threw them off. "Let's forget about Judas," or, "Of course, he is gone to hell," but, you know, who is the resurrection for?

Ashley Makar: And what about images and objects you consider of religious significance in your home?

Shep Parsons: We have a collection of menorahs, which are just gorgeous. We have an artist friend who made one of them, it has dancing figures coming out and in their hands they hold the candles. Candles are very important. That and lighting of the candles and, of course, Iris and Eli [Parson's children] are always in contention about who's going to get to blow them out. I have some of my paintings hanging at the house. And for me, they're really important because painting is such a spiritual experience. I said earlier I like color, I don't draw very well but I love to play with color. And so I may start out a painting thinking that I'm going to go in a particular direction, but it's really, I know it's cliché, but it's like a journey. I don't really know where it's going turn out, a mistake, do 
I get over it or do I incorporate it and the brokenness gets worked into the whole? And so that when something is up there [on the wall], it takes me back to a time and place but also to something I went into and in some ways it's still there.

Ashley Makar: What about in your worship spaces?

Shep Parsons: Shelton, I just love the simplicity. There's table and very modest cross. Sometimes we move it. There's a big wooden cross up here that somebody made and gave and so its there in perpetuity. But it's funny because except when folks sing the Gloria Patri or Matri, the focus is, the eye is down. It's down at the bronze cross on the table. And we move it. So one Sunday the cross may be down in front of the table, maybe up on the side of the table with something else, balancing it on the table or on either side. But I think that really is focus. We have a pulpit and a lectern but the aisle leads right down to the cross, central. It's just so simple.

Ashley Makar: Which images do you think are most prevalent and meaningful to people in your congregation?

Shep Parsons: Table and the cross. You know, it's central. It's the first thing you see when you walk in and actually the glint of the bronze cross will catch your eye before the big wooden cross. The light shines on it and it reflects. It has stained windows that are gorgeous and there are times when the sun is streaming in, this gives this beautiful kind of yellow hue. You walk into the place and you immediately feel safe. There are no images of men in there, just motifs of flowers, that kind of thing.

Ashley Makar: Okay. So no human figures. And what role does either the physical space or nature and the environment play in your worship?

Shep Parsons: Well, the church [Shelton] was built 1892 to provide a place of worship for the workers and the managers of the factory. It's up the hill. It sits right on the lip of the flood plain and so it has a commanding view. It's right across the street from the managerial folks, the workers had to walk a ways and there are pictures of people with buggies driving up to it, but everybody walked. And they had a parsonage. They have a parish house and a parsonage next to it. And they sold the parsonage but it has no parking, none whatsoever. Back in the 9os, the church growth people said a church will only grow as big as its parking lot. And so people are very much aware of where we sit, where we sit in the community.

We sit on the hill. Beautiful street, we're right across from City Hall. I think on the one hand it reminds us of from where we've come, not just of our physical limitations, and it looks down on the floodplain, factories and the apartment houses.

(C) Ashley Makar 


\section{Citation Guide}

1. Ashley Makar, "Shep Parson on Material Culture and Protestant Ministry," Interview, in MAVCOR Journal 1, no. 1 (2017), doi:10.22332/mav.int.2017.3

Makar, Ashley. "Shep Parson on Material Culture and Protestant Ministry." Interview. In MAVCOR Journal 1, no. 1 (2017). doi:10.22332/mav.int.2017.3

\section{Notes}

1. Center Church on the Green in New Haven, CT has a large stained glass window of the Reverend John Davenport preaching his first sermon in New Haven on April 25, 1638. The window, situated above the pulpit and altar and the end of the sanctuary, was designed by Joseph Lauber at Tiffany Studios (New York), and depicts the first Sunday worship for New Haven's settlers in the wilderness of the Quinnipiack territory.

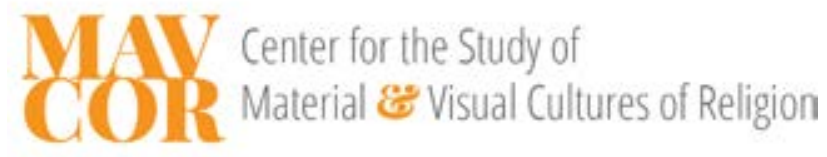

\section{Yale}

Copyright 2016 Yale University All rights reserved.

MAVCOR Joumal is a born-digital, double-blind peer-reviewed publication of the Center for the Study of Material and Visual Cultures of Religion at Yale University

(mavcor.yale.edu). 